Tropical Journal of Pharmaceutical Research May 2019; 18 (5): 1027-1032

ISSN: 1596-5996 (print); 1596-9827 (electronic)

(1) Pharmacotherapy Group, Faculty of Pharmacy, University of Benin, Benin City, 300001 Nigeria.

\title{
Tetrazole exerts anti-hepatitis effect in mice via activation of PI3K/Akt pathway, inhibition of cell autophagy and suppression of inflammatory cytokine expressions
}

\author{
Bin Chen, Junshan Yang* \\ Department of Hepatology, Wuwei People's Hospital, Wuwei 733000, China \\ ${ }^{*}$ For correspondence: Email: TMarzullonske@yahoo.com; Tel: +86-0935-5820091
}

Sent for review: 5 October 2018

Revised accepted: 17 April 2019

\begin{abstract}
Purpose: To investigate the effect of tetrazole on concanavalin A (Con A)-induced hepatitis in mice, and the underlying mechanism(s).

Methods: Thirty 5-week-old, male BALB/c mice (mean weight, $30.5 \pm 1.04 \mathrm{~g}$ ) were used for this study. They were randomly assigned to six groups of five mice each: control group, hepatitis group and four treatment groups. With the exception of control group, hepatitis was induced in all mice with Con $A$ (20 $\mathrm{mg} / \mathrm{kg}$ ) via their tail veins. The treatment groups received varied doses of tetrazole $(1.0-6.0 \mathrm{mg} / \mathrm{kg})$ within $1 \mathrm{~h}$ after hepatitis induction, while mice in the control group received an equivalent volume of normal saline in place of tetrazole. Serum activities of alanine aminotransferase (ALT) and aspartate aminotransferase (AST) were determined while expressions of interleukin-2 (IL-2), tumor necrosis factor $\alpha$ (TNF- $\alpha$ ), and interferon gamma (IFN- $\gamma$ ) were evaluated by enzyme-linked immunosorbent assay (ELISA) kits. Expressions of protein kinase B (Akt), phosphoinositide 3-kinase (PI3K), nuclear transcription factor- $\kappa B(N F-\kappa B)$, and autophagy-related genes were determined by real-time quantitative polymerase chain reaction (qRT-PCR) and Western blotting.

Results: Con A-induced hepatitis significantly increased the activities of serum ALT and AST in the mice. However, after treatment with tetrazole, the activities of these enzymes were significantly and dose-dependently reduced in the treatment groups, relative to hepatitis group $(p<0.05)$. The levels of IL-2, IFN- $\gamma$ and TNF- $\alpha$ were significantly increased in hepatitis group when compared with the control group $(p<0.05)$. However, treatment with tetrazole significantly inhibited the expressions of these parameters. There were no significant differences in the levels of expressions of Akt mRNAs among the treatment groups $(p>0.05)$. The levels of expressions of LC3II and Beclin 1 were also significantly upregulated in hepatitis group, when compared with control group $(p<0.05)$. However, expression levels of LC3II and Beclin 1 were significantly and dose-dependently reduced by tetrazole treatment Conclusion: Tetrazole is effective in the treatment of hepatitis via mechanisms involving the activation of PIJK/Akt pathway, inhibition of cell autophagy and suppression of inflammatory cytokines expressions.
\end{abstract}

Keywords: Hepatitis, Concanavalin A, Tetrazole, Inflammatory cytokines, Expression, Autophagy

This is an Open Access article that uses a fund-ing model which does not charge readers or their institutions for access and distributed under the terms of the Creative Commons Attribution License (http://creativecommons.org/licenses/by/4.0) and the Budapest Open Access Initiative (http://www.budapestopenaccessinitiative.org/read), which permit unrestricted use, distribution, and reproduction in any medium, provided the original work is properly credited.

Tropical Journal of Pharmaceutical Research is indexed by Science Citation Index (SciSearch), Scopus, International Pharmaceutical Abstract, Chemical Abstracts, Embase, Index Copernicus, EBSCO, African Index Medicus, JournalSeek, Journal Citation Reports/Science Edition, Directory of Open Access Journals (DOAJ), African Journal Online, Bioline International, Open-J-Gate and Pharmacy Abstracts 


\section{INTRODUCTION}

Hepatitis is a liver disease caused by viral infection, exposure to toxins, excessive alcohol consumption and immunological disturbance $[1,2]$. Its pathogenesis is complex and involves several pathways and molecules [3-5]. The disease progression involves activation of $T$ cells which in turn stimulate the secretion of inflammatory cytokines and enzymes in the blood $[6,7]$. The activities of ALT and AST, and levels of inflammatory cytokines are usually elevated in the blood following the activation of T cells $[8,9]$.

Concanavalin $\mathrm{A}$ (Con $\mathrm{A}$ ), a plant lectin, activates $T$ lymphocytes [10]. Liver damage in hepatitis is caused by aggregation and infiltration of $\mathrm{T}$ lymphocytes [11,12]. In addition, the expressions of IL-2, TNF- $\alpha$ and IFN- $\gamma$ are involved in the pathogenesis of hepatitis [13]. Nuclear transcription factor- kappa $\mathrm{B}(\mathrm{NF}-\kappa \mathrm{B})$ regulates the expressions of inflammatory cytokines in hepatitis [13]. However, the activity of NF- $\kappa \mathrm{B}$ is regulated by $\mid \kappa \mathrm{B} \alpha$ with the involvement of PI3K/Akt pathway [13]. Autophagy, a type of programmed cell death acts by engulfing cellular organelles in the form of autophagosomes and transfering them to lysosomes for degradation $[14,15]$. The autophagic process is regulated by activation of several pathways such as C-Jun- $\mathrm{N}$ and AMPK. The formation of an autophagosome involves Beclin 1 and mTOR pathways which are regulated by the PI3K/Akt pathway $[16,17]$.

The four nitrogen atoms in tetrazole ring are responsible for the biological activity of the compound. Tetrazole-bearing compounds possess chemotherapeutic effects such as antiinflammatory, antimicrobial, anti-nociceptive and anticonvulsant activities [18]. There is a need for the development of new and effective chemotherapeutic agents that can effectively ameliorate the symptoms and complications of hepatitis. The aim of this study was to investigate the effect of tetrazole on Con A-induced hepatitis in mice, and the underlying mechanism(s).

\section{EXPERIMENTAL}

\section{Materials}

The BALB/c mice were purchased from Beijing HFK Bioscience Co., Ltd., while ALT and AST automated biochemical analyser was a product of Olympus AU1000 (Japan). ELISA kits were purchased from Santa Cruz Biotechnology Inc. (USA), while Kinematica tissue pulverizer was obtained from Shanghai Xin Yu Biotech Co., Ltd. RNeasy Mini kit was purchased from Qiagen, Inc. (USA) and NanoDrop 1000 spectrophotometer was obtained from Thermo
Fisher Scientific Inc. (USA). Real time polymerase chain reaction (RT-PCR, 7900HT model) was a product of $A B I$ (USA), while SYBR Premix EX Taq was obtained from Takara Biotechnology Inc. (Japan).

\section{Mice}

A total of thirty 5-week-old BALB/c male mice weighing 28.2 to $32.8 \mathrm{~g}$ (mean weight $=30.5 \pm$ $1.04 \mathrm{~g})$ were used for this study. They were housed in plastic cages under standard conditions of animal care and had free access to standard feed and water. The mice were exposed to $12 \mathrm{~h}$ light/dark cycles and maintained at $25{ }^{\circ} \mathrm{C}$ and $48 \%$ humidity. The study protocol was approved by the Laboratory Animal Committee of China Medical University (approval no. CMU/17/187), and the study procedures were carried out according to the guidelines of National Institutes of Health [19].

\section{Treatment}

The mice were randomly assigned to six groups of five mice each: control group, hepatitis group and four treatment groups. With the exception of control group, hepatitis was induced in the mice with Con A $(20 \mathrm{mg} / \mathrm{kg})$ through their tails veins. The treatment groups received varied doses of tetrazole $(1.0-6.0 \mathrm{mg} / \mathrm{kg}$ bwt) within $1 \mathrm{~h}$ after induction of hepatitis, while mice in the control group received equivalent volumes of normal saline.

\section{Determination of activities of ALT and AST, and serum levels of inflammatory cytokines}

After $12 \mathrm{~h}$ of treatment, the mice were sacrificed under isoflurane anaesthesia and blood samples were collected through cardiac puncture. The blood was centrifuged at $3000 \mathrm{rpm}$ for $30 \mathrm{~min}$ at room temperature to obtain serum which was used for biochemical analysis. Serum activities of ALT and AST were determined using automated biochemical analyser, while the expressions of IL-2, TNF- $\alpha$, and IFN- $\gamma$ were determined using appropriate ELISA kits.

\section{Western blotting}

Liver tissues collected from the mice were stored in liquid nitrogen at $-80{ }^{\circ} \mathrm{C}$ and sliced into thin sections $(5 \mu \mathrm{m})$ using refrigerated microtome, and homogenized using Kinematica tissue pulveriser. The resultant tissue homogenate was washed twice with phosphate-buffered saline (PBS) and centrifuged at $13,000 \mathrm{~g}$ for $25 \mathrm{~min}$ at 4 ${ }^{\circ} \mathrm{C}$. The protein concentration of the supernatant was determined using BCA assay kit. A portion 
of total tissue protein $(20-30 \mu \mathrm{g})$ from each sample was separated on a $12 \%$ sodium dodecyl sulphate (SDS)-polyacrylamide gel electrophoresis and transferred to a fixed polyvinylidene fluoride membrane at $110 \mathrm{~V}$ and $90^{\circ} \mathrm{C}$ for $120 \mathrm{~min}$.

Subsequently, non-fat milk powder (3\%) in Trisbuffered saline containing $0.2 \%$ Tween-20 (TBS$\mathrm{T})$ was added with gentle shaking at $37{ }^{\circ} \mathrm{C}$ and incubated to block non-specific binding of the blot. Incubation of the blots was performed overnight at $4{ }^{\circ} \mathrm{C}$ with primary antibodies of IL-2, TNF- $\alpha$, IFN- $\gamma$, AKT, p-AKT, PI3K, p-P13K, LC3II, Beclin 1 and $\beta$-actin at a dilution of 1 to 500 . Then, the membrane was washed thrice with TBS-T and further incubated with horseradish peroxidase-conjugated goat anti-rabbit IgG secondary antibody for $1 \mathrm{~h}$ at room temperature. The blot was developed using an X-ray film. Grayscale analysis of the bands was performed using ImageJ analysis software (4.6.2). Respective protein expression levels were normalized to that of $\beta$-actin which was used as a standard reference.

\section{Quantitative polymerase chain reaction (qRT- PCR)}

Total RNAs were isolated from portions of liver homogenate using RNeasy Mini kit and determined spectrophotometrically. The RNAs were reverse-transcribed to cDNAs, using random primers at $45{ }^{\circ} \mathrm{C}$ for $2 \mathrm{~h}$. The samples were heated at $95{ }^{\circ} \mathrm{C}$ for $10 \mathrm{~min}$. The PCR amplification of the reverse-transcribed reaction mixture was carried out using $20 \mu$ reaction mixture and equal volume of SYBR Premix Ex TaqTM II. The PCR conditions were: predenaturation at $95{ }^{\circ} \mathrm{C}$ for $30 \mathrm{sec}$, denaturation at $95{ }^{\circ} \mathrm{C}$ for $3 \mathrm{sec}$, annealing at $60{ }^{\circ} \mathrm{C}$ for $34 \mathrm{sec}$, and 50 cycles. The procedure was performed in triplicate. Relative expression was quantified using Stratagene Mx3000P software, and $\beta$-actin gene was used as internal reference. The primers sequences used for qRT-PCR are shown in Table 1.

Table 1: Primers sequences used for qRT-PCR

\begin{tabular}{lll}
\hline Gene & \multicolumn{2}{c}{ Primer sequence } \\
\cline { 2 - 3 } s & Forward & Backward \\
\hline Interle & TGAGCAGGATGGA & GTCCAAGTTCATCT \\
ukin-2 & GAATTACAGG & TCTAGGCAC \\
TNF- $\alpha$ & CAGGCGGTGCCTAT & CGATCACCCCGAA \\
& GTCTC & GTTCAGTAG \\
Interfe & ATGAACGCTACACA & CCATCCTTTTGCCA \\
ron- $\gamma$ & CTGCATC & GTTCCTC \\
Beclin & ATGGAGGGGTCTAA & TGGGCTGTGGTAA \\
1 & GGCGTC & GTAATGGA \\
LC3II & GACCGCTGTAAGGA & AGAAGCCGAAGGT \\
\hline
\end{tabular}

\begin{tabular}{lll} 
& GGTGC & TTCTTGGG \\
PI3K & ACACCACGGTTTGG & GGCTACAGTAGTG \\
& ACTATGG & GGCTTGG \\
Akt & ATGAACGACGTAGC & TTGTAGCCAATAAA \\
& CATTGTG & GGTGCCAT \\
$\beta-$ & GGCTGTATTCCCCT & CCAGTTGGTAACAA \\
actin & CCATCG & TGCCATGT \\
\hline
\end{tabular}

\section{Statistical analysis}

Data are expressed as mean $\pm S D$, and the statistical analysis was performed using SPSS (11.5). Groups were compared using Student's $t$ test. $P<0.05$ was considered statistically significant.

\section{RESULTS}

\section{Serum ALT and AST}

Con A-induced hepatitis significantly increased the activities of serum ALT and AST in the mice. However, after treatment with tetrazole, the activities of these enzymes were significantly and dose-dependently decreased in the treatment groups, relative to hepatitis group $(p<0.05)$. Their activities in hepatitis mice treated with 6 $\mathrm{mg} / \mathrm{kg}$ bwt tetrazole were $62 \pm 19 \mathrm{U} / \mathrm{L}$ and $131 \pm$ $32 \mathrm{U} / \mathrm{L}$, respectively (Figure 1 ).

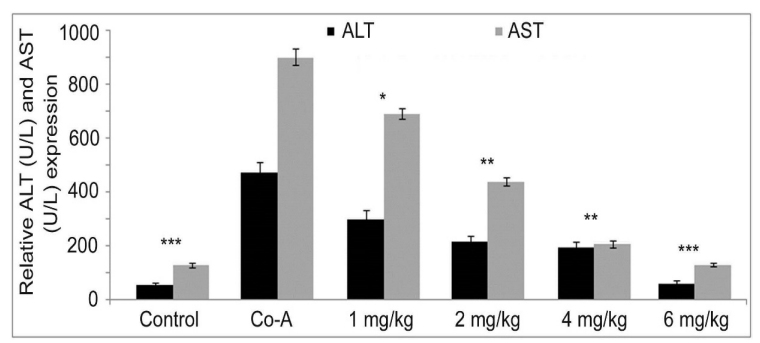

Figure 1: Effect of tetrazole treatment on the activities of ALT and AST; ${ }^{*} p<0.05,{ }^{* *} p<0.01$ and ${ }^{* * *} p<0.001$, when compared to hepatitis group

\section{Inflammatory cytokines}

The expression levels of IL-2, IFN- $\gamma$ and TNF- $\alpha$ were significantly increased in hepatitis group, when compared with the control group $(p<0.05)$. However, treatment with $6 \mathrm{mg} / \mathrm{kg}$ tetrazole producing the most significant inhibition $(p<$ 0.05 ). These results are shown in Figure $2 \mathrm{~A}$ and B.

\section{Expressions of Akt and PI3K}

As shown in Figures $3 \mathrm{~A}$ and $\mathrm{B}$, the expressions of Akt and PI3K were significantly and dosedependently enhanced in treatment groups, when compared with the control and hepatitis groups $(p<0.05)$. However, there were no significant differences in the levels of 
expressions of Akt mRNAs among the treatment groups $(p>0.05)$. The expressions of $p$-Akt and $\mathrm{p}$-PI3K were also significantly higher in the treatment groups than in the hepatitis group $(p<$ 0.05).

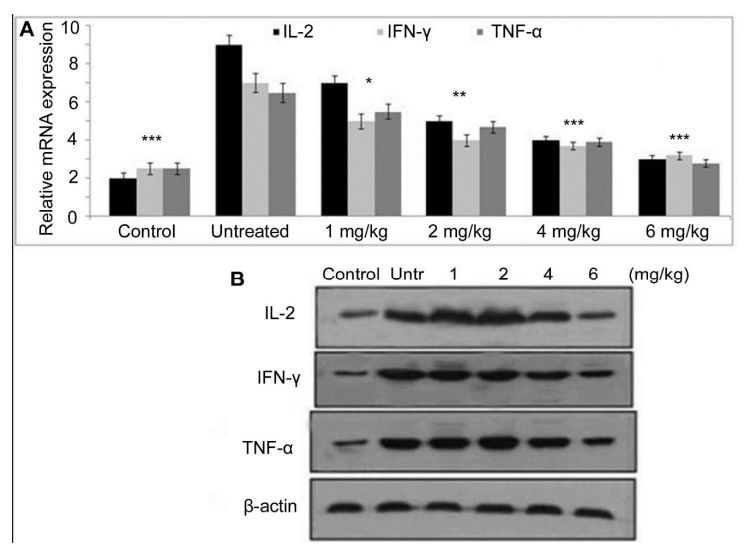

Figure 2: Effect of tetrazole on the levels of inflammatory cytokines in hepatitis mice; $\mathbf{A}$ : Expressions of inflammatory cytokines as determined using qRT-PCR; B: Expressions of inflammatory cytokines as determined using Western blotting. ${ }^{*} p<$ $0.05,{ }^{* *} p<0.01$ and ${ }^{* *} p<0.001$, when compared to hepatitis group

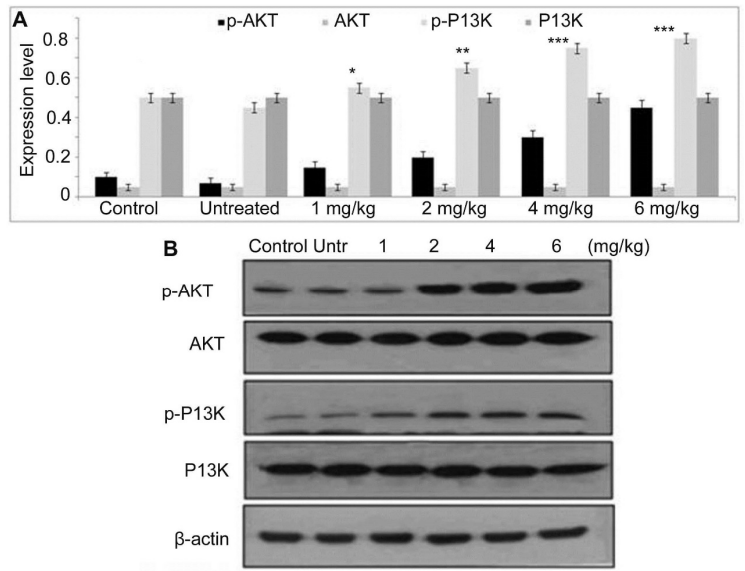

Figure 3: Effect of tetrazole on the level of expressions of Akt and PI3K in hepatitis mice; $\mathbf{A}$ : expressions of Akt and PI3K as determined using qRT-PCR; B: expressions of Akt and P13K as determined using Western blotting; $* p<0.05$, ${ }^{* *} p<$ $0.01^{* * *} p<0.001$, when compared to control group

\section{Effect of tetrazole treatment on NF- $\kappa \mathrm{B}$ pathway}

The expression of NF- $\kappa$ B was significantly higher in hepatitis group than in control group, but was significantly and dose-dependently reduced after treatment with tetrazole $(p<0.05)$. However, the expressions of $1 \kappa \mathrm{B} \alpha$ and $1 \kappa \mathrm{B} \beta$ were significantly upregulated in control and treatment groups, relative to hepatitis group $(p<0.05$; Figure 4$)$.

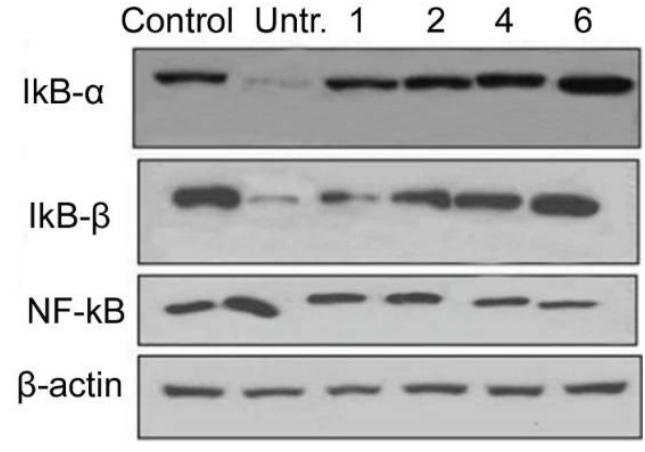

Figure 4: Effect of tetrazole treatment on $\mathrm{NF}-\kappa \mathrm{B}$ expression

\section{Expressions of autophagy-related genes}

The expressions levels of LC3II and Beclin 1 were significantly upregulated in hepatitis group, when compared with control group $(p<0.05)$. However, LC3II and Beclin 1 were significantly and dose-dependently downregulated by tetrazole treatment, with $6 \mathrm{mg} / \mathrm{kg}$ bwt tetrazole producing maximum inhibition (Figures $5 \mathrm{~A}$ and B).

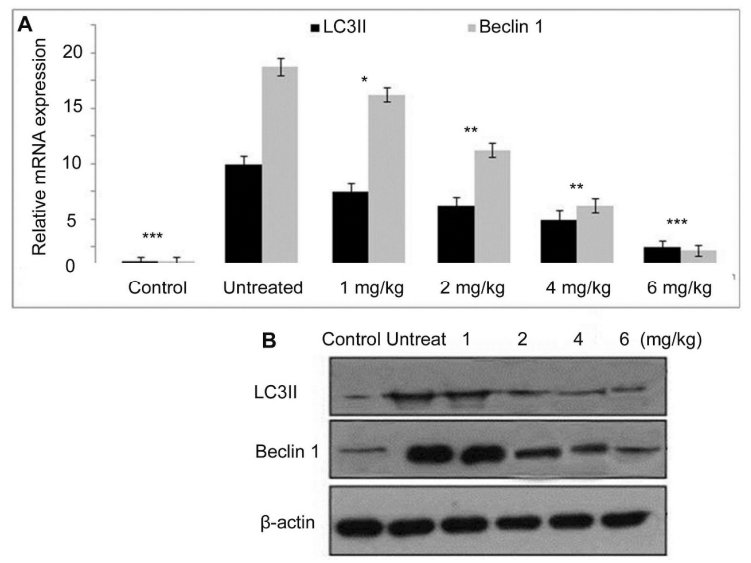

Figure 5: Beclin 1and LC3II expressions in the mice. A: Expressions of LC3II and Beclin 1 as determined using qRT-PCR; B: Expressions of LC3̋ll and Beclin 1 as determined using Western blotting; $p<0.05, " * p<$ 0.01 and ${ }^{* *} p<0.001$, compared to control group

\section{DISCUSSION}

Hepatitis is a serious health condition caused by viral infection, exposure to toxins, excessive alcohol consumption and immunological disturbance [1]. At present, there are no effective therapeutic agents for hepatitis [19]. The present study investigated the effect of tetrazole on Con A-induced hepatitis in mice, and the underlying mechanism (s). Induction of hepatitis leads to release of inflammatory cytokines such as TNF$\alpha$, IFN- $\gamma$, IL-2 and IL-6 [20]. In this study, the levels of IL-2, IFN- $\gamma$ and TNF- $\alpha$ were significantly increased in hepatitis group when compared with 
the control group. However, treatment with tetrazole significantly inhibited the expressions of these parameters, with $6 \mathrm{mg} / \mathrm{kg}$ bwt tetrazole producing the most significant inhibition. These results are in agreement with those reported in previous studies [20]. It is possible that tetrazole regulated the secretion of these inflammatory cytokines in Con A- induced hepatitis mice.

Increased activities of serum ALT and AST are associated with liver damage [12]. In this study, Con A-induced hepatitis significantly increased the activities of serum ALT and AST in the mice. However, after treatment with tetrazole, the activities of these enzymes were significantly and dose-dependently reduced in the treatment groups, relative to hepatitis group. These results suggest that tetrazole may prevent liver damage in hepatitis by inhibiting the release of inflammatory cytokines. It is likely that the upregulation of inflammatory cytokine expressions enhances the activities of ALT and AST in serum of hepatitis mice.

Expressions of genes associated with the secretion of inflammatory cytokines are regulated by NF- $\kappa \mathrm{B}$ [21]. Nuclear transcription factor- $\kappa \mathrm{B}$ (NF- $\kappa$ B) plays a key role in the expression of proinflammatory genes and the development of hepatitis $[22,23]$. The results of Western blotting showed that the expression of $\mathrm{NF}-\kappa \mathrm{B}$ was significantly higher in hepatitis group than in control group, but was significantly and dosedependently reduced after treatment with tetrazole. However, the levels of expressions of $1 \kappa \mathrm{B} \alpha$ and $1 \kappa \mathrm{B} \beta$ were significantly upregulated in control and treatment groups, relative to hepatitis group. These results suggest that the pathogenesis of hepatitis may involve the degradation of $\mathrm{NF}-\kappa \mathrm{B}$, and that tetrazole might prevent $I_{\kappa} \mathrm{B}-\alpha$ and $I_{\kappa} \mathrm{B}-\beta$ degradation. It is likely that treatment with tetrazole suppressed the translocation of $\mathrm{NF}-\kappa \mathrm{B}$ to the nucleus of hepatocytes in hepatitis mice. It has been reported that inhibition of $\mid \kappa \mathrm{B}-\alpha$ and $\mid \kappa \mathrm{B}-\beta$ degradation plays a central role in downregulation of the expressions of inflammatory factors [24]. Induction of cell autophagy is regulated by several factors, the most common of which are PI3K and Akt [14].

In the present study, the expressions of Akt and PI3K were significantly and dose-dependently increased in treatment groups, when compared with the control and hepatitis groups. However, there were no significant differences in the levels of expressions of Akt mRNAs among the treatment groups. The levels of expressions of $p$ Akt and $\mathrm{p}-\mathrm{PI} 3 \mathrm{~K}$ were also significantly higher in the treatment groups than in hepatitis group.
These results suggest that tetrazole exerts antihepatitic effects via the activation of PI3K/Akt pathway. In this study, treatment with tetrazole significantly down-regulated the expressions of Beclin 1 and LC3II, an indication that tetrazole may exert anti-hepatitis effect via the inhibition of cell autophagy.

\section{CONCLUSION}

Tetrazole is effective in the treatment of hepatitis and its anti-hepatitis effect is exerted via mechanisms involving the activation of PI3K/Akt pathway, inhibition of cell autophagy and suppression of inflammatory cytokine expressions.

\section{DECLARATIONS}

\section{Conflict of interest}

No conflict of interest is associated with this work.

\section{Contribution of authors}

We declare that this work was done by the authors named in this article and all liabilities pertaining to claims relating to the content of this article will be borne by the authors.

\section{Open Access}

This is an Open Access article that uses a funding model which does not charge readers or their institutions for access and distributed under the terms of the Creative Commons Attribution License (http://creativecommons.org/licenses/by/ 4.0) and the Budapest Open Access Initiative (http://www.budapestopenaccessinitiative.org/rea d), which permit unrestricted use, distribution, and reproduction in any medium, provided the original work is properly credited.

\section{REFERENCES}

1. Tu CT, Yao $Q-Y, X u B L$, Zhang SC. Curcumin protects against concanavalin A-induced hepatitis in mice through inhibiting the cytoplasmic translocation and expression of high mobility group box 1 . Inflammation 2013; 36: 206-215.

2. Verma S, Thuluvath PJ. Complementary and alternative medicine in hepatology: review of the evidence of efficacy. Clin Gastroenterol Hepatol 2007; 5: 408-416.

3. Bozza M, Bliss JL, Maylor R. Interleukin-11 reduces $T$ cell-dependent experimental liver injury in mice. Hepatol 1999; 30: 1441-1447. 
4. Nunnari G, Schnell MJ. MicroRNA-122: a therapeutic target for hepatitis $C$ virus (HCV) infection. Frontiers Biosci (Scholar) 2011; 3: 1032-1037.

5. Lupberger J, Zeisel MB, Xiao F. EGFR and EphA2 are host factors for hepatitis $C$ virus entry and possible targets for antiviral therapy. Nature Medicine 2011; 17: 589-595.

6. Miyazawa $Y$, Tsutsui $H$, Mizuhara $H$, Fujiwara $H$, Kaneda $K$. Involvement of intrasinusoidal hemostasis in the development of concanavalin A-induced hepatic injury in mice. Hepatol 1998; 27: 497-506.

7. Takeda K, Hayakawa Y, van Kaer L, Matsuda H, Yagita $H$, Okumura K. Critical contribution of liver natural killer $T$ cells to amurine model of hepatitis. Proceedings of the National Academy of Sciences of the United States of America 2000; 97: 5498-5503.

8. Gantner F, Leist M, Lohse AW, Germann PG, Tiegs G. Concanavalin A-induced T-cell-mediated hepatic injury in mice: the role of tumor necrosis factor. Hepatol 1995; 21: 190-198.

9. Kusters S, Gantner F, Kunstle G, Tiegs G. Interferon gamma plays a critical role in $T$ cell-dependent liver injury in mice initiated by concanavalin A. Gastroenterol 1996; 111: 462-471.

10. Tiegs G, Hentschel J, Wendel A. A T cell-dependent experimental liver injury in mice inducible by concanavalin A. J Clin Invest 1992; 90: 196-203.

11. Hong $F$, Jaruga B, Kim WH. Opposing roles of STAT1 and STAT3 in $T$ cell-mediated hepatitis: regulation by SOCS. J Clin Invest 2002; 110: 1503-1513.

12. Tu CT, Han B, Liu HC, Zhang SC. Curcumin protects mice against Concanavalin A-induced hepatitis by inhibiting intrahepatic intercellular adhesion molecule-1 (ICAM-1) and CXCL10 expression. Molecular Cellular Biochem 2011; 358: 53-60.

13. Mizuhara H, O'Neill E, Seki N, Ogawa T, Kusunoki C, Otsuka K, Satoh S, Niwa M, Senoh H, Fujiwara H. T cell activation associated hepatic injury: mediation by tumor necrosis factors and protection by interleukin 6. Journal of Experimental Medicine 1994; 179: 1529-1537.

14. Murrow L, Debnath J. Autophagy as a stress-response and quality-control mechanism: Implications for cell injury and human disease. Annual Review of Pathology: Mechanisms of Disease 2013; 8: 105-137.

15. Mizushima N, Levine B, Cuervo AM, Klionsky DJ. Autophagy fights disease through cellular self-digestion. Nature 2008; 451: 1069-1075.

16. Ding, WX, Ni, HM, Gao, W, Yoshimori, T, Stolz, DB, Ron, $D$, Yin, $X M$. Linking of autophagy to ubiquitinproteasome system is important for the regulation of endoplasmic reticulum stress and cell viability. Am J Pathol 2007; 171: 513-524.

17. Roy B, Pattanaik AK, Das J, Bhutia SK, Behera B, Singh P, Maiti TK. Role of PIJK/Akt/mTOR and MEK/ERK pathway in concanavalin $A$ induced autophagy in HeLa cells. Chemico-Biological Interactions 2014; 210: 96101.

18. Zhang HZ, Lin JM, Rasheed S, Zhou CH. Design, synthesis, and biological evaluation of novel benzimidazole derivatives and their interaction with calf thymus DNA and synergistic effects with clinical drugs. Science China Chemistry 2014: 57: 807-822.

19. Czaja AJ. Hepatic inflammation and progressive liver fibrosis in chronic liver disease. World Journal of Gastroenterology 2014; 20: 2515-2532.

20. Zhou Y, Dai W, Lin C, Wang F, He L, Shen M, Chen $P$, Wang $C$, Lu J, Xu L, Xu X, Guo C. Protective effects of necrostatin-1 against concanavalin A-induced acute hepatic injury in mice. Mediators Inflamm 2013; 2013, Article ID 706156.

21. Baldwin AJ. The NF-kappa B and I kappa B proteins: new discoveries and insights. Annual Review of Immunology 1996; 14: 649-683.

22. Li $Q$, Verma IM. NF- $\kappa B$ regulation in the immune system. Nature Reviews Immunology 2002; 2: 725-734.

23. Chen K, Li J, Wang J, Xia Y, Dai W, Wang F, Shen $M$, Cheng $P$, Zhang $Y$, Wang $C$, Yang J, Zhu $R$, Zhang $H$, Zheng Y, Lu J, Fan Z, Zhou Y, Guo C. 15-deoxy-gamma 12,14-prostaglandin $\mathrm{J} 2$ reduces liver impairment in a model of ConA induced acute hepatic inflammation by activation of PPAR gamma and reduction in NF-kappa $B$ activity. PPAR Res 2014; 2014, 215631.

24. Hoesel B, Schmid JA. The complexity of NF- $\kappa B$ signalling in inflammation and cancer. Molecul Cancer 2013; 12 : 86. 